\title{
1. Introduction: using qualitative research methods for educational research
}

\author{
Michael R.M. Ward and Sara Delamont
}

\section{INTRODUCTION}

In this chapter we introduce and outline the second edition of the Handbook of Qualitative Research in Education. We focus here on the three core principles that shape the book and how we divide the book up into four sections. These four sections concentrate on the theoretical and disciplinary perspectives of research in education; the non-school settings qualitative educational research takes place in; how data are collected; and finally, how data are analysed and presented in various ways. We then discuss the changes we have made from the first edition and describe the chapters that make up this Handbook.

\section{THE CORE PRINCIPLES}

The core principles underlying this edition are the same as those that were central to the original edited by Sara Delamont in 2012. They are, first, that many different methods of data collection, analysis and 'publication' are available to qualitative researchers, each with its strengths and weaknesses. Scholars, we believe, should make informed choices to suit their research questions from the range of available methods we have showcased in this volume. Second, 'educational' research should never be synonymous with doing studies in schools (see Allen, 2018). Teaching and learning take place in many settings, inside and beyond formal organisations (see Ward, 2018; Ward et al., 2017). Insights about instructors or students or both can be gained from research in, and applied to, those processes in any context. So research on apprentice mosque builders in the Yemen can provide insight into the socialisation process in medical schools, and vice versa. Third, drawing on feminist perspectives (see Oakley, 1981), researchers' own reflections are also important (see Ward, 2016) when conducting qualitative research and must be written into author accounts of methods and methodology.

The Introduction to the first edition (Delamont, 2012a) argued the case for these core principles using an elaborate metaphor about the four great gates of the medieval city of Damascus as described in Flecker's (1947) famous poem. The argument for the core principles was first outlined in a keynote plenary at the Australian and New Zealand annual educational research conference in 2003, and published later (Delamont, 2005). That metaphor is not repeated here, but the Handbook maintains its fundamental message and contains chapters on educational research in a variety of non-school settings. Insights from scholarship done in any of these non-school settings can be useful in research on schools as well as interesting and thought-provoking in their own right (Delamont, Atkinson and Pugsley, 2010). The range of settings in which qualitative research on teaching and learning can be studied is also apparent 


\section{Handbook of qualitative research in education}

from the 68 papers collated in Delamont (2012b), which include research on firefighters, skateboarders and capoeira players.

These core principles are represented via the four parts of the book, which we still feel in this edition best represent how qualitative research in education is conducted. These are the theoretical and disciplinary perspectives of research in education (Chapters 2-10), the diverse non-school settings qualitative educational research takes place in (Chapters 11-20), the methods and methodology used to collected this research (Chapters 21-32) and finally how data are analysed and presented in various ways (Chapters 33-43). The next section elaborates more on the changes we have made and the content of the new edition.

\section{THE NEW EDITION}

The first edition of this Handbook came out in 2012 and was edited by Sara Delamont. This new edition edited by Michael R.M. Ward and Sara Delamont is a different book in four ways. First of all it has two editors, who brought different experiences of the field to the task. The new co-editor (Ward) is from the generation of qualitative educational researchers who undertook their doctoral research in the 21 st century, in an intellectual landscape very different from Delamont's experience in the 1970s. Furthermore Ward $(2015,2018)$, continuing a theme we hold throughout this revised edition, and developing earlier work by Delamont and colleagues (Delamont and Atkinson, 1995; Delamont, Atkinson and Pugsley, 2010), has conducted educational research that goes beyond formal educational settings. In two new edited collections with Sadia Habib, Ward takes this work further still to focus on youth and belonging in multiple international settings (see Habib and Ward, 2019, 2020).

Second, the revised edition, which comprises 43 entries, has 25 entirely new chapters by new authors. These authors are drawn from various career stages and offer insights into areas of scholarship that were untouched in the first volume or have emerged since. For example, theoretically we felt it was essential to include a chapter on Critical Race Theory (see Halldórsdóttir and Kjaran, Chapter 6) and qualitative work conducted in research settings that have developed apace since 2012, such as academies/charter schools (see Morrin, Chapter 20), online spaces (see Tummons, Chapter 16; Robson, Chapter 31) and data collected through innovative visual research methodology (Mannay and Turney, Chapter 21; Habib, Chapter 32; Cortazzi and Jin, Chapter 43). Other new chapters focus on ethics in qualitative research (Calder, Chapter 9), the process of conducting longitudinal educational research (Neale, Chapter 10), adult education (Kosonen, Chapter 17), playwork (King, Chapter 18), homeschooling (Myers, Chapter 19) and thematic analysis (Terry and Hayfield, Chapter 38).

Third, the various chapters that appeared in the 2012 volume have all been revised and updated by their original authors. These include history and education (Tamboukou, Chapter 4), feminist perspectives on educational research (Allan, Chapter 5), research conducted using indigenous methods (Bishop, Chapter 8), teacher education (Dressman, Journell and Mann, Chapter 14), non-formal education (Roth, Chapter 15), photographic methods (Louise Allen, Chapter 22), mobile methods (Kusenbach, Chapter 23), life histories (Clemens and Tierney, Chapter 24), gathering narrative data (Elliott, Chapter 25), focus groups (Robinson, Chapter 30), transcription (Hammersley, Chapter 33), analysis of narratives (Watson and Mcluckie, Chapter 34), qualitative analysis with 28 questions (Cortazzi and Jin, Chapter 35), analysis of fieldnotes (Corwin and Clemens, Chapter 36), writing textual genres (Somerville, Chapter 39), 
dance as research dissemination (Bagley and Castro-Salazar, Chapter 40), drama as a form of dissemination (Holmes, Chapter 41) and experimental art (Gitlin, Chapter 42).

Other chapters have new authors but cover the same topics as the 2012 volume; for example, the sociology of education (Delamont, Chapter 2), the anthropology of education (Sánchez, Chapter 3), queer theory (Loutzenheiser, Chapter 7), vocational education (Atkins, Chapter 11), professional education (Thomas, Chapter 12), higher education (Finn and Holton, Chapter 13), documents and archives (Grant, Chapter 26), traditional ethnography (McInch, Chapter 27), autoethnography (Gannon, Chapter 28), interviewing individuals (Marvasti and Tanner, Chapter 29) and software to support qualitative data analysis (Paulus and Lester, Chapter 37).

Finally, some topics such as testimonio, and memory books, have been dropped and replaced by new ones of current importance, for example academies and online learning and researching spaces.

The countries represented by the authors are also diverse and highlight the international aspect of qualitative research in education. Contributors come from all four corners of the United Kingdom (England, Northern Ireland, Scotland and Wales), North America (Canada and the US), Australia, New Zealand, Iceland, Finland and the UAE. The Handbook also presents research that draws on studies undertaken in Malaysia and China.

Before we bring this introduction to a close and turn the Handbook over to the authors, we want to thank them for their contributions and for working with us and responding to our own comments and critique as well as those from the anonymous reviewers. For Ward, it has been a pleasure to have been part of this second edition and to highlight the innovative research being done by emerging and established scholars both in the UK and beyond.

\section{NOTE}

1. The authors' 2012 chapter contained 19 questions.

\section{REFERENCES}

Allen, A. (2018) 'Using the once familiar to make the familiar strange once again: engaging with historical inquiry and autobiography in contemporary ethnographic research', Qualitative Research, 18(5), $538-553$.

Delamont, S. (2005) 'Four great gates', Research Papers in Education, 20(1), 85-100.

Delamont, S. (2012a) 'Introduction: leaving Damascus'. In S. Delamont (ed.), Handbook of Qualitative Research in Education. Cheltenham, UK and Northampton, MA, USA: Edward Elgar Publishing, 1-20.

Delamont, S. (ed.) (2012b) Ethnographic Methods in Education (four volumes). London: Sage.

Delamont, S. and Atkinson, P. (1995) Fighting Familiarity. Cresskill, NJ: Hampton Press.

Delamont, S., Atkinson, P. and Pugsley, L. (2010) 'The concept smacks of magic', Teaching and Teacher Education, 25(1), 3-10.

Flecker, E. (1947) Collected Poems. London: Secker \& Warburg.

Habib, S. and Ward, M.R.M. (eds) (2019) Identities, Youth and Belonging: International Perspectives. Basingstoke: Palgrave Macmillan.

Habib, S. and Ward, M.R.M. (eds) (2020) Youth, Place and Theories of Belonging. Oxford: Routledge.

Oakley, A. (1981) Subject Woman. London: Martin Robertson.

Ward, M.R.M. (2015) From Labouring to Learning: Working-Class Masculinities, Education and De-Industrialization. Basingstoke: Palgrave Macmillan. 


\section{Handbook of qualitative research in education}

Ward, M.R.M. (ed.) (2016) Gender Identity and Research Relationships. Studies in Qualitative Methodology, Vol. 14. Bingley: Emerald.

Ward, M.R.M. (2018) 'Acceptable masculinities: working-class young men and vocational education and training courses', British Journal of Educational Studies, 66(2), 225-242.

Ward, M.R.M., Tarrant, A., Terry, G., Robb, M., Featherstone, B. and Ruxton, S. (2017) 'Doing gender locally: the importance of "place" in understanding young men's masculinities in the male role model debate', The Sociological Review, 65(4), 797-815. 